\title{
4849F, a New Metabolite Produced by the Streptomyces sp. 4849 as an Inhibitor of IL-4 Receptor
}

\author{
Ke Wang, Lianhong Guo, Yingshu Zou, Yuan Li, Jianbo Wu
}

Received: March 14, 2007 / Accepted: April 28, 2007

(C) Japan Antibiotics Research Association

\begin{abstract}
A new compound named 4849F was isolated from the Streptomyces sp. 4849. The structure of 4849F was elucidated by spectroscopic analyses. The immobilized ligand-binding assay showed that $4849 \mathrm{~F}$ can competitively inhibit the binding of IL-4 with IL-4 receptor in a dose dependent manner with an $\mathrm{IC}_{50}$ value of $6.7 \mu \mathrm{M}$.
\end{abstract}

Keywords 4849F, IL-4, IL-4R, inhibitor

IL-4 is a pleiotropic type I cytokine produced by activated $\mathrm{T}$ cells, mast cells, and basophils $[1,2]$. It is considered important in the development of allergic inflammation and airway hyperresponsiveness (AHR). The overlap of its function results from the IL-4R-chain forming an important functional signaling component of both the IL-4 and IL-13 receptors [3]. Consequently, inhibition of the receptorligand interaction may offer an effective way to interfere the biological effect of IL-4. In the course of searching for IL-4 receptor inhibitors, a novel compound, 4849F (Fig. 1) was isolated from the Streptomyces sp. 4849 which had been deposited in CCGMC. In this paper, we described fermentation, isolation, structure elucidation and bioactivity of $4849 \mathrm{~F}$.

A slant culture of the Streptomyces sp. 4849. was maintained on an agar slant. After incubation at $28^{\circ} \mathrm{C}$ for 7 days, the slant was inoculated into $50 \mathrm{ml}$ medium composed of yeast extract $0.5 \%$, glucose $0.5 \%$, tryptone $0.5 \%$, beef extract $0.5 \%$, corn steep liquten $0.4 \%$, soybean extract $1.0 \%$, starch $2.0 \%, \mathrm{CaCO}_{3} 0.4 \%$. in $500-\mathrm{ml}$

J. Wu (Corresponding author), K. Wang, L. Guo, Y. Zou, Y. Li: Institute of Medicinal Biotechnology, Chinese Academy of Medical Science \& Peking Union Medical College, Tiantanxili No 1, Beijing 100050, P.R. China, E-mail: wujb0825@sohu.com
Erlenmeyer flasks. The fermentation was performed on a rotary shaker with $250 \mathrm{rpm}$ at $28^{\circ} \mathrm{C}$ for 4 days. The filtrate (5 liters) obtained by filtration of fermentation broth was applied to an Amberlite XAD-5 column $(4.5 \times 35 \mathrm{~cm})$, washed with distilled water and eluted with $\mathrm{Me}_{2} \mathrm{CO}-\mathrm{H}_{2} \mathrm{O}$ $(1: 1)$. The eluted material was concentrated and then extracted with EtOAc. The EtOAc extract was concentrated and applied to a silica gel column $(2.5 \times 30 \mathrm{~cm})$ and eluted with $\mathrm{CHCl}_{3}$ - EtOAc $(5: 1)$. The first yellow band was further separated using the silica gel column $(2 \times 20 \mathrm{~cm})$ eluted with cyclohexane-EtOAc $(2: 1)$. Pure $4849 \mathrm{~F}$ was obtained in an amount of $4.0 \mathrm{mg}$.

The physico-chemical properties of $4849 \mathrm{~F}$ are shown in Table 1 . The UV spectrum of $4849 \mathrm{~F}$ showed absorption maximum at $270 \mathrm{~nm}$. The molecular formula of 4849F was established to be $\mathrm{C}_{14} \mathrm{H}_{12} \mathrm{O}_{2} \mathrm{~N}_{2}$ by HR ESI-MS. The ${ }^{1} \mathrm{H}-\mathrm{NMR}$ $(400 \mathrm{MHz})$ and ${ }^{13} \mathrm{C}-\mathrm{NMR}(100 \mathrm{MHz})$ spectral data of 4849F are shown in Table 2.

The ${ }^{1} \mathrm{H}-\mathrm{NMR}$ spectrum showed methoxy protons $(\delta 4.18)$, and aromatic protons $(\delta 7.10,7.74$ and 8.00). The ${ }^{13} \mathrm{C}-\mathrm{NMR}$ showed seven signals among which six are aromatic carbons and one is methoxy carbon. When considered together, molecular formula and the NMR signals indicated 4849F had a symmetrical structure which had two same phenyl group and methoxy group.

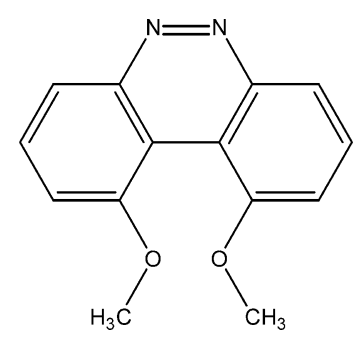

Fig. 1 Structure of 4849F. 
Table 1 Physico-chemical properties of 4849F

\begin{tabular}{ll}
\hline Appearance & Yellow needles \\
Melting point & $233 \sim 235^{\circ} \mathrm{C}$ \\
Molecular formula & $\mathrm{C}_{14} \mathrm{H}_{12} \mathrm{O}_{2} \mathrm{~N}_{2}$ \\
HR ESI-MS $(\mathrm{m} / \mathrm{z})$ & \\
Found $(\mathrm{M}+\mathrm{H})^{+}$ & 241.0971 \\
Calcd & 241.0977 \\
UV $\lambda_{\max }^{\mathrm{MeOH}} \mathrm{nm}$ & 270 \\
\hline
\end{tabular}

Table $2{ }^{1} \mathrm{H}$ - and ${ }^{13} \mathrm{C}-\mathrm{NMR}$ spectral data of $4849 \mathrm{~F}$ recorded in $\mathrm{CDCl}_{3}$

\begin{tabular}{llc}
\multicolumn{1}{c}{ Position } & \multicolumn{1}{c}{${ }^{1} \mathrm{H}$} & ${ }^{13} \mathrm{C}$ \\
\hline 1,8 & $8.00(\mathrm{~d}, \mathrm{~J}=8.0 \mathrm{~Hz})$ & 122.1 \\
$1 \mathrm{a}, 8 \mathrm{a}$ & & 143.0 \\
2,7 & $7.74(\mathrm{t}, \mathrm{J}=8.0 \mathrm{~Hz})$ & 130.1 \\
3,6 & $7.10(\mathrm{~d}, \mathrm{~J}=8.0 \mathrm{~Hz})$ & 106.9 \\
4,5 & & 154.9 \\
$4 \mathrm{a}, 5 \mathrm{a}$ & & 136.9 \\
$4-\mathrm{OCH}_{3}, 5-\mathrm{OCH}_{3}$ & $4.18(\mathrm{~s})$ & 56.5 \\
\hline
\end{tabular}

Connectivities from $\mathrm{C}-1$ to $\mathrm{C}-2$, and $\mathrm{C}-2$ to $\mathrm{C}-3$ were established by the ${ }^{1} \mathrm{H}-{ }^{1} \mathrm{H}$ COSY spectrum. The elucidated structure of $4849 \mathrm{~F}$ was similar to the skeleton of phenanthrene which contained a structure of pyridazine. Given the simplicity of the NMR data presented, there were really only two possibilities for the site of attachment of the methoxy groups, given the proton coupling pattern observed in the COSY spectrum of the compound, either at $\mathrm{C}-4$ or at $\mathrm{C}-1$, since the three aromatic protons were contiguous. Furthermore, from the HMBC correlation data we knew, if the methoxy group was at the site of C-1 $(\delta 154.9)$, it should show the connection of $\mathrm{H}(\delta 7.74)$ with $\mathrm{C}-1(\delta$ 154.9), C-4a $(\delta 136.9)$ and $\mathrm{C}-1 \mathrm{a}(\delta 143.0)$. In fact it only showed the connection of $\mathrm{H}(\delta 7.74)$ with $\mathrm{C}-1$ $(\delta$ 154.9) and $\mathrm{C}-1 \mathrm{a}(\delta$ 143.0). It was 4-bond coupling between $\mathrm{H}(\delta$ 7.74) and $\mathrm{C}-1 \mathrm{a}(\delta 143.0)$, but only 3-bond coupling between $\mathrm{H}(\delta$ 7.74) and $\mathrm{C}-4 \mathrm{a}(\delta$ 136.9). So the methoxy group must be at the site of C-4. The structure of 4849F was showed in Fig. 2.

The bioactivity of $4849 \mathrm{~F}$ was evaluated in the immobilized ligand-binding assay method. The preparation of reagents and experimental procedures have been described in detail by Zhang [4]. Briefly, $100 \mu 1$ of $2.0 \mu \mathrm{g} / \mathrm{ml} \mathrm{IL}-4$ was coated onto a 96-well immunoplate overnight at $4{ }^{\circ} \mathrm{C}$, then with $250 \mu \mathrm{l} /$ well of $3.0 \%$ BSA in PBS $(0.05 \mathrm{M}$ phosphate buffer, $\mathrm{pH} 7.2,0.15 \mathrm{M} \mathrm{NaCl})$ for 8

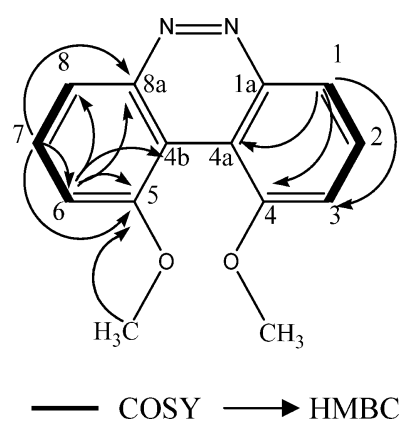

Fig. $2{ }^{1} \mathrm{H}^{1} \mathrm{H}$ COSY and $\mathrm{HMBC}$ correlations of $4849 \mathrm{~F}$.

hours at $4{ }^{\circ} \mathrm{C}$, followed by washing with PBST $(0.1 \%$ Tween 20 in PBS). $50 \mu 1$ samples were mixed with $50 \mu \mathrm{l}$ sIL-4R. Then $100 \mu \mathrm{l}$ of the mixtures were added to the plate and incubated overnight at $4^{\circ} \mathrm{C} .100 \mu \mathrm{l} /$ well of mouse monoclonal anti-human IL-4R antibody (diluted in PBSA) were added, incubated at $4^{\circ} \mathrm{C}$ for 1 hour. Then $100 \mu \mathrm{l} /$ well of $1: 1000$ dilution of horseradish peroxidase (HRP)labeled horse monoclonal anti-mouse $\operatorname{IgG}(\mathrm{H}+\mathrm{L})$ in PBST was added and incubated as above. After the final wash, $100 \mu \mathrm{l} /$ well TMB solution (3,3',5,5-tetramethyl benzidine dihydrochloride) was added to each well and reaction took place at room temperature for 1 hour at room temperature. $100 \mu \mathrm{l}$ of $2 \mathrm{~N} \mathrm{HCl}$ were added to end the reaction. The absorbance at $450 \mathrm{~nm}$ was recorded as measurement of the reaction. $4849 \mathrm{~F}$ inhibited the binding of IL-4 to IL-4R in a dose dependent manner with an $\mathrm{IC}_{50}$ value of $6.7 \mu \mathrm{M}$.

4849F has no activity for both of Gram-positive bacterias and Gram-negative bacterias. The MTT assays showed that the novel compound $4849 \mathrm{~F}$ has cytotoxicities for human breast cancer MCF-7 and human ovarian cancer A2780 cell lines with $\mathrm{IC}_{50} 6.8 \mu \mathrm{M}$ and $5.6 \mu \mathrm{M}$ respectively [5]. Other bio-activities of 4849F are under investigation.

Acknowledgement The study was supported by the National Science Foundation of China. (NSFC, 30370038).

\section{References}

1. Chol P, Reiser H. IL-4: role in disease and regulation of production. Clin Exp Immunol 113: 317-319 (1998)

2. Paul WE. Interleukin-4: a prototypic immunoregulatory lymphokine. Blood 77: 1859-1870 (1991)

3. Tomkinson A, Duez C, Cieslewicz G, Pratt JC, Joetham A, Shanafelt MC, Gundel R, Gelfand EW. A murine IL-4 receptor antagonist that inhibits IL-4- and IL-13-induced responses prevents antigen-induced airway eosinophilia and 
airway hyperresponsiveness. J Immunol 166(9): 5792-5800 (2001)

4. Zhang Y, Wang WC, Li Y. Cloning, expression, and purification of soluble human interleukin-4 receptor in Streptomyces. Protein Expr Purif 36: 139-145 (2004)
5. Masuda T, Wada K, Nakajima A, Okura M, Kudo C, Kadowaki T, Kogo M, Kamisaki Y. Critical role of peroxisome proliferator-activated receptor $\gamma$ on anoikis and invasion of squamous cell carcinoma. Clin Cancer Res 11(11): 4012-4021 (2005) 